\title{
ENSURING A BALANCE BETWEEN PUBLIC AND PRIVATE INTERESTS IN THE IMPLEMENTATION OF QUARANTINE MEASURES
}

ASEGURANDO UN EQUILIBRIO ENTRE LOS INTERESES PÚBLICOS Y PRIVADOS EN LA IMPLEMENTACIÓN DE LAS MEDIDAS DE CUARENTENA

Yaroslav Lazur*

Tetyana Karabin **

Oleksander Martyniuk ${ }^{* * *}$

Oleksandr Bukhanevych ${ }^{* * * *}$

Oksana Kanienberh-Sandul ${ }^{* * * * *}$

\begin{abstract}
Under the influence of the spread of coronavirus infection, the world community has faced difficult challenges that provoke changes in the seemingly already stabilized legal regulation, putting at risk the settlement of human rights and the common good. The study aims to find effective
\end{abstract}

\footnotetext{
* Doctor of Legal Science, Professor, Acting Dean of the Faculty of Law of Uzhhorod National University (Uzhhorod, Ukraine). https://orcid.org/0000-0002-7520-7167. lazurs80@gmail.com

** Doctor of Legal Science, Associate Professor Head of Department of administrative, financial and informative law of Uzhhorod National University (Uzhhorod, Ukraine). https://orcid.org/0000-0002-6538-5269. tetyana.karabin@uzhnu.edu.ua

*** Ph. D., Lecturer, Department of Criminal Law and Procedure, Ternopil National Economic University (Ternopil, Ukraine). https://orcid.org/0000-0001-5226-070X. martynyuk007@ukr.net

***** Doctor of Legal Science, Professor, Head of the Department of Constitutional, Administrative and Financial Law, Khmelnytsky University of Management and Law named after Leonid Yuzkov, Honored Lawyer of Ukraine (Khmelnytsky, Ukraine). https://orcid.org/0000-0003-3718-9428. omb.ukr@gmail.com

${ }^{* * * * *} \mathrm{Ph}$. D., Associate Professor of Department of International and European Law, National University "Odesa Law Academy" (Odesa, Ukraine). https://orcid.org/0000-0002-80073335. kanenberg1990@gmail.com
} 


\section{Y. Lazur, T. Karabin, O. Martyniuk, O. Bukhanevych \& O. Kanienberh-Sandul}

mechanisms for balancing human rights and public interests in the context of their legal regulation. Specifically, this study is focused on the mechanisms of balancing private and public interests in the implementation of quarantine measures in the Covid-19 pandemic. The research methods were both general scientific and special methods, in particular: formal legal, historical and legal, analysis and synthesis. To perform the tasks of the work, the following structure was used: after some initial precisions, there are provided some considerations about the fiscal stimulus measures and about the exercise of the right of derogation; then, the study deals with the problem of lawmaking in a pandemic; and finally it is considered the threats to intellectual property in the sphere of healthcare. The results of the work show that the pandemic has seriously hit the balance between private and public interests. The public interests of the government and society have become a priority, but in many cases, the measures that infringe private interests are disproportionate, untimely and inefficient.

Keywords: Balance of Public and Private Interests, Violation of Rights, Pandemic Consequences, Pharmaceutical Patents, Ineffectiveness of Governments

Resumen: Bajo la influencia de la propagación de la infección por coronavirus, la comunidad mundial se ha enfrentado a desafíos difíciles que provocan cambios en la regulación aparentemente ya estabilizadas, poniendo en riesgo el sistema de derechos humanos y el bien común. Este estudio tiene como objetivo encontrar mecanismos efectivos para equilibrar los derechos humanos y los intereses públicos en el contexto de su regulación legal vigente. En concreto, se estudian aquí los mecanismos de equilibrio de los intereses públicos y privados en la implementación de medidas de cuarentena en la pandemia del Covid-19. Los métodos de investigación fueron métodos científicos generales y especiales tales como dialéctico, sistémico, estructural, formal-legal, histórico-legal, así como técnicas epistemológicas como análisis, y síntesis. Para realizar las tareas del trabajo, se utilizó la siguiente estructura: después de algunas precisiones, se trata sobre las medidas de estímulo fiscal y sobre el ejercicio del derecho de derogación; luego, se entra a ver el problema de la elaboración de leyes en una pandemia; finalmente, se aborda el tema de las amenazas a la propiedad intelectual en el ámbito de la salud. Los resultados del trabajo muestran que la pandemia ha afectado seriamente el equilibrio entre los intereses públicos y privados. Los intereses públicos del gobierno y la sociedad se han convertido en una prioridad, pero en muchos casos, las 
medidas que vulneran los intereses privados son desproporcionadas, inoportunas e ineficientes.

Palabras clave: Equilibrio de intereses públicos y privados, violación de derechos, consecuencias de una pandemia, patentes farmacéuticas, ineficacia de los gobiernos

Summary. I. Introduction. II. Analysis of recent research. III. Results and discussion. III.1. Precisions and Terminological Nuances. III.2. Budgetary Stimulus Measures. III.3. Exercise of the Right of Derogation. III.4. The Problem of Legislation in a Pandemic. III.5. Threats to Intellectual Property in Healthcare. IV. Conclusions. References.

\section{INTRODUCTION}

The Universal Declaration of Human Rights (1948) (hereinafter "the Declaration") has established the basic limits of acceptable behavior for all individuals. Such powers and freedoms under this international law treaty include the right to life, liberty, the security of person (Article 3), the recognition of legal personality (Article 6), equality before the law and the courts (Article 7); effective renewal of their rights (Article 8), freedom of privacy and family life, inviolability of the home, the secrecy of correspondence, honor, and reputation, and protection of the law against interference with or infringement of such rights (Article 12), freedom of migration (Article 13), thoughts, conscience, and religion (Article 18), beliefs (Article 19), peaceful assemblies and associations (Article 20), and in Part 2 of Art. Article 29 of the Declaration stipulates that in exercising their rights and freedoms, everyone should be subject only to such limitations as are prescribed by law solely to ensure the proper recognition and respect of the rights and freedoms of others and to ensure fair moral, public order and the general welfare in a democratic society.

The European Convention on Human Rights (1950) (hereinafter "the Convention") details the above rules. Particular attention in the context of our study is Article 15 of this international treaty, which states that in an emergency that threatens the life of the nation, any signatory state may take measures that derogate from its obligations under the Convention, but only to the extent proportionate and provided that such measures do not contradict its other international legal obligations (McBride, 2020). The Constitution of Ukraine (1996) stipulates that human life and health are recognized in Ukraine as the highest social value (Article 3). Article 55 guarantees the right of a person to judicial protection. Also, the main legal act of the country 
prohibits the narrowing of the content and scope of existing rights and freedoms, except cases such as the imposition of martial law or a state of emergency (Kryvorot \& Martynenko, 2020).

The inalienable and inviolable human right to life and health is also confirmed by the Fundamentals of the legislation of Ukraine on health care, as well as the obligation of the state to take care of them. At the same time, liability is established for violation of the norms of this normative legal act (Article 80; Schukin, 2020).

The Law of Ukraine "On Ensuring the Sanitary and Epidemic Welfare of the Population" specifies how sanitary-epidemic, sanitary-hygienic control must be observed by government officials, local self-government, and regulates the rights and obligations associated with it. Article 40 of this normative legal act regulates the procedure for quarantine (Kovalenko, 2020).

Article 29 of the Law of Ukraine "On protection of the population from infectious diseases" regulates the procedure for quarantine in Ukraine. The preamble also states its goals, objectives, methods of regulation, which include ensuring the state of epidemiological safety, mechanisms to combat the spread of infectious diseases (Kravets, 2020).

Figure 1. Consideration of cases under Art. 44-3 of the Code of Administrative Offenses (1984) as of June 30, 2020.

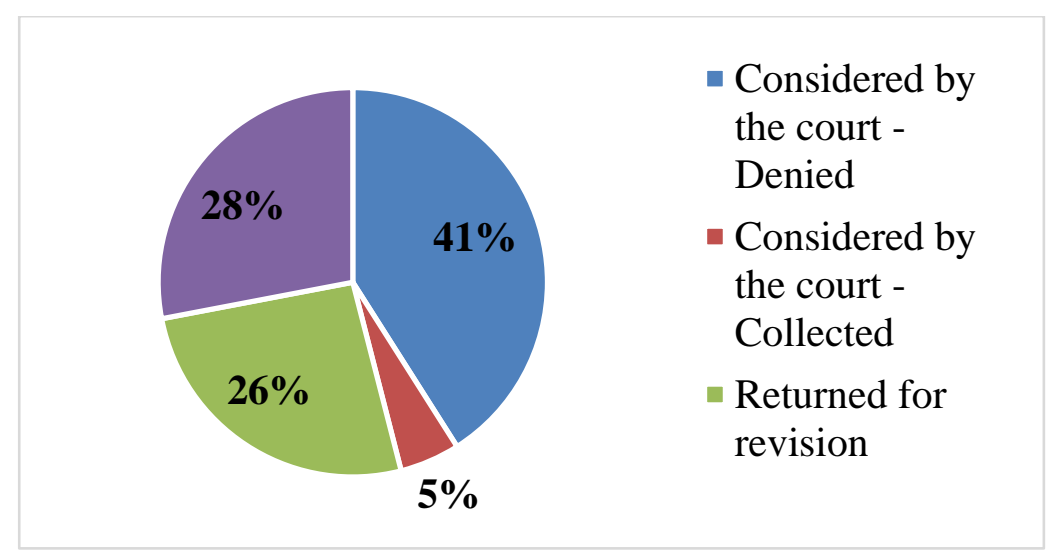

To prevent the occurrence and spread of acute respiratory disease Covid-19 caused by the SARS CoV-2 virus, the Cabinet of Ministers of Ukraine issued Resolution $\mathrm{n}^{\circ} 211$ of March 11, 2020, which introduced quarantine throughout Ukraine. On March 25, 2020, the government introduced a state of emergency throughout Ukraine (Ivashchenko \& Nazarets, 2020). 
Subsequently, in order to stimulate compliance with quarantine measures, the Verkhovna Rada adopted Law n ${ }^{\circ}$ 530-IX of March 17, 2020, according to which amendments were made to the legislation on administrative and criminal liability. In particular, Art. 44-3 "Violation of the rules on quarantine of people" and introduced enhanced sanctions for a period of three months under Art. 325 of the Criminal Code (2002), which expired on June 18, 2020, in connection with which the norm of Art. 325 of the Criminal Code returned to its previous version (State Juridical Administration, 2020). The situation on consideration of cases under Art. 44-3 of the Code of Administrative Offenses (1984) "Violation of the rules on quarantine of people" as of June 30, 2020 can be illustrated in Figure 1.

Therefore, given the complexity of the situation facing the world community, legislator, and legal science, it is necessary to comprehensively consider this multifaceted problem in various aspects of jurisprudence, as it manifests itself not only in certain areas of law but to some extent for the whole array of legal regulation, similarly to how the Covid-19 pandemic affects every area of human life.

\section{ANALYSIS OF RECENT RESEARCH}

Firstly, it should be noted, that Tikhomirov (1995), Syrovatskyi (2019), Koval (2000), Kolomiets (2004), Galunko (2020), Maidanyk (2015), Savchenko (2013), Zharovska (2010), Konfudorova (2020) devoted their research to theoretical issues of concepts of private and public interest. In their articles, scholars analyzed the features, as well as suggested possible interpretations of legal terminology related to the subject of the study, outlined the problems of legal regulation.

Moreover, McBride, Senyuta (2020a; 2020b), Kravets (2020), Kovalenko (2020), Kryvorot and Martynenko (2020) and Yarovyi (2020) devoted their publications to the topical issue of the limits of interference with human rights, reasonableness, proportionality, and rationality of quarantine restrictions. In their works, the authors considered from the point of view of national and international law the admissibility of such interventions of state institutions in human rights and identified situations in which it is appropriate, and in which - is a violation of human rights.

A very valuable and useful opinion regarding the interaction and interpenetration of the private and public spheres (from the standpoint of administrative law) Barnes (2018) expressed in his article "An Expanding Frontier of Administrative Law: The Public Life of Private Actors". Also, attention was focused on the works of foreign scientists who deeply studied 
the problems of mutual influence of chat and public interests, as Gabardo (2017), Comparato (2017), Strauss (2016) and Varuhas (2016).

In terms of fair access to treatment, the issue of ensuring the balance of public and private interests in the implementation of quarantine measures was considered by such scholars as Buletsa, Kharytonova (2020), Zaliska and Stasiv (2019), Kashintseva and Trofimenko (2020), Mazurenko (2020) and Chepis (2020).

Among the foreign experts on this topic are the names of Ferrario and Kanavos (2013), Wenzl and Chapman (2019). All of them, in one way or another, studied the subject of this article from different points of view: from remedies outside the instructions and for reasons of humanity to conflicts of intellectual property law and the application of the TRIPS agreement (1994) to the issuance of compulsory licenses for drugs used to combat the new coronavirus. It can be stated that in some way all the above scientists and researchers have come to the conclusion that it is necessary to introduce reasonable quarantine restrictions, which will ensure fair access to medicines, treatments, diagnostics, etc. not only in developed countries but also in middle and low-income countries, which will certainly be a favorable factor in maintaining a balance of public and private interests. It should be noted that the above-mentioned scholars often see the overcoming of barriers in intellectual property law as a legal mechanism to ensure such a balance, which is connected with the application of the TRIPS agreement and the issuance of compulsory licenses for medicines.

Scholars such as Senyuta (2020a, 2020b) and Safarov (2020) paid attention to the issues of information policy of the state in the conditions of the Covid-19 pandemic, protection of personal data, individual rights to the secrecy of correspondence, private life, and access to public information. In particular, Senyuta (2020a) draws attention to the legal conflicts related to the processing of personal data related to the measures taken to counteract the spread of Covid-19. Emphasis is placed on the inadmissibility of violating a person's right to privacy, as well as the priority of finding flexible mechanisms that will ensure respect for human rights in a pandemic. In turn, Safarov (2020) noted that under current legislation, a person's right to access socially important information can not be limited under any circumstances, including the implementation of quarantine measures.

From the point of view of labor law, social security, the issue of balancing public and private interests in quarantine was considered by such lawyers as Golosnichenko (2020), Schukin (2020), Savchuk (2020). In their publications, jurists considered current changes in the relevant legislation, analyzed the existing problems of legal regulation, such as the legality of dismissal of employees based on quarantine, the rate of payment for forced 
downtime, etc. It is concluded that the volume of labor disputes will increase in the future under the influence of the consequences of restrictive measures.

Nevertheless, despite the work of domestic and foreign scholars to strike a balance between public and private interests in connection with the pandemic and the corresponding restrictive measures of governments, this issue is gaining new meaning and context. It is important to analyze the new problems that have arisen in this area and consider solutions.

\section{RESULTS AND DISCUSSION}

\section{III.1. Precisions and Terminological Nuances}

The pandemic, government measures, and the economic crisis have affected many spheres of the ordinary life of society, but the hardest hit came precisely on the points of contact of public and private interests in completely different areas. Let's look at examples of different spheres of how the relationship between public and private subjects of the relationship is changing.

As a result of the above events, there has been controversy in society and in the scientific community as to whether quarantine restrictions are legal and how to balance private and public interests at such a difficult time. For example, the Kharkiv Human Rights Group expressed doubts about the legality of the imposed restrictions, in particular, regarding the powers of the Cabinet of Ministers to restrict the constitutional rights and freedoms of citizens (Legal Newspaper Online, 2020).

Concerning human rights restrictions, article 29 of the Universal Declaration of Human Rights (Universal Declaration (1948) proclaims:

(2) In the exercise of his rights and freedoms, everyone shall be subject only to such limitations as are determined by law solely for the purpose of securing due recognition and respect for the rights and freedoms of others and of meeting the just requirements of morality, public order and the general welfare in a democratic society.

Thus, human rights may not be restricted voluntarily. There must be serious reasons, connected with the violation of public order or morality. As for the common good principle (general welfare principle according to the Universal Declaration), the situation is not obvious.

Finnis (2011) stresses that the Declaration misuses the concept of common good (general welfare), which may not be a proper (distinct and separate) ground for limiting rights. The author explains that the concept of common good includes the rights, also proclaimed by the Universal Declaration. They are life, liberty, security of person, equality before the 
law, privacy, marriage and protection of family life, property, social security and the 'realization of the economic, social and cultural rights indispensable for dignity and the free development of his personality, participation in government, work, protection against unemployment, favorable remuneration of work, rest and leisure, «a standard of living adequate for (...) health and well-being (...)», education, enjoyment of the arts and a share in the benefits of scientific advancement, and «a social and international order in which the rights and freedoms set forth in this Declaration can be fully realized».

Thus, the general welfare is not a proper concept for limitation of one's rights and freedoms. Otherwise, the list of reasons would be almost endless.

Here we would like to draw attention to the fact that even before the spread of coronavirus infection in the scientific community there was no single point of view on the very concepts of public and private interest, and taking both into account in implementing regulatory mechanisms requires a flexible model that takes into account which is also the subject of discussion, so it seems appropriate to start with a brief outline of modern discourse on the concepts of public and private interest.

It should be noted that in terms of terminology, attempts have been made to define the public interest through a set of private interests or its "quintessential" meaning for the functioning and progress of the state, so some scholars see epistemological preconditions for the use of state coercion as a mandatory that as a means of guaranteeing fundamental social (universal) values such as life, health, family, property, etc., it can not be something universal under any circumstances, so it must be constantly improved to harmonize with private interests, which are also constantly upgraded. (Galunko, 2020; Zharovska, 2010); Koval, 2000; Kolomiets, 2004; Konfudorova, 2020; Maidanyk, 2015; Savchenko, 2013; Savchuk, 2020; Slusar \& Novikova, 2020; Kharytonova, 2020).

We support Dworkin's understanding of the correlation between private and public interest in the context of human rights. Dworkin (1978) argues that when we seek to improve the general welfare, external preferences should be excluded - because they undermine the «basic right to equal concern and respect» which is a fundamental political right- «a postulate of political morality». They have this effect because any imposition of external preferences is equivalent to a judgment that those on whom they are imposed are inferior, not to be treated as equals or «with equal concern and respect».

Dworkin (1978) expresses his view in such a quote: 
«The idea of rights as trumps is a formal idea: it fixes the general function of rights within any particular theory that uses the idea at all. We can therefore think about the content of rights at two different levels of analysis. When we are engaged in constructing a general political theory, we must consider what package-what general justification for political decisions together with what rights - is most suitable (...). But on other occasions we must take the general scheme of some political theory as fixed and consider what rights are necessary as trumps over the general background justification that theory proposes» (p. 281).

The concept of distinguishing between public and private interests as the interests of the state and society on the one hand and the interests of individuals on the other was supported by Ukrainian lawyer Maidanyk (2015). He also tried to define the concept of public interest through the harmonization of private and public, public benefit, or social effect from the partnership of private and public actors.

In this context, the idea of public interest as meeting the needs common to society (in the context of this work, the state) as a whole, i.e., such ideas, principles, opinions, aspirations, ideals, values, norms, etc., which do not differ between individual social groups, and the private interest - as ensuring the rights, freedoms, and interests of individuals.

According to Art. 1 of the Law of Ukraine "On Prevention of Corruption" (2014), private interest is recognized as any property or nonproperty interest of a person, including due to personal, family, friendly, or other non-official relations with individuals or legal entities, including those arising in connection with "membership or activity in public, political, religious or other organizations".

The Constitutional Court of Ukraine in its decision of 1 December $2004 \mathrm{n}^{\circ} 18-\mathrm{rp} / 2004$ states that «a legally protected interest» is a desire to use a specific tangible and/or intangible good as conditioned by the general content of objective law and not directly mediated in the sub effective law is a simple legitimate permit, which is an independent object of judicial protection and other remedies to meet individual and collective needs that do not contradict the Constitution and laws of Ukraine, public interests, justice, good faith, reasonableness, and other common law principles.

The practice of the Constitutional Court confirms that the rights and freedoms of man and citizen guaranteed by the Constitution of Ukraine can be limited only in exceptional cases. In its decisions, the Constitutional Court emphasizes two criteria for the admissibility of such restrictions: proportionality and social necessity, from which it can be concluded that restrictions on the constitutional rights and freedoms of man and citizen are 
justified only, when they: (i) legal; (ii) proportional (proportionate); and (iii) socially necessary (Chervonenko, 2020).

According to Art. 4 of the Law of Ukraine $n^{\circ} 1550-\mathrm{III}$ "On the legal regime of the state of emergency" (2000), the pandemic is considered the legal basis for the imposition of a state of emergency, as a result of which according to Art. 64 of the Constitution of the country may restrict certain human rights, such as those referred to in Art. 33 of the Constitution (freedom of movement). However, the view that this right may be legally restricted only in the event of martial law or a state of emergency is erroneous, since in the event of a danger of the spread of infectious diseases it may be restricted in accordance with Art. 12 of the Law of Ukraine "On Freedom of Movement and Free Choice of Residence in Ukraine" (2004), which does not contradict the Constitution. In this context, the restrictive measures introduced by the Cabinet of Ministers cannot be considered illegal, as such powers are provided by the Constitution, the Law "On the Cabinet of Ministers of Ukraine" (2011), the Law "On protection of the population against infectious diseases" $n^{\circ}$ 1645-III of April 6, 2000.

However, the ban on visiting parks, forest parks, etc. during walks, training, or running as part of restrictive measures of freedom of movement can be questioned in terms of proportionality and social necessity, which will result in questionable constitutionality of the set of restrictions on freedom of movement in general, as it is difficult to justify the expediency and proportionality of such prohibitions in terms of rationality and common sense, given all known information about the features of Covid-19, especially since the authorities themselves eventually recognized the demonstrative nature of such measures (Chervonenko, 2020).

Thus, we have a situation when the rights and freedoms of people are violated as a preventive measure, and even after it becomes clear which measures are effective (mask mode, ban on large gatherings of people) and which are not (stopping transportation, banning leaving the house), the government reacts not quite adequate.

\section{III.2. Budgetary Stimulus Measures}

The states choose different models of countering the coronavirus and different spending patterns - from generous coverage of wages and rental costs (Germany, Sweden) to exclusively medical purposes of the coronavirus budget (India, South Africa), which is due to many factors. 
Figure 2. Morbidity and mortality in \%.

Data provided by the Ministry of Finance (2020)

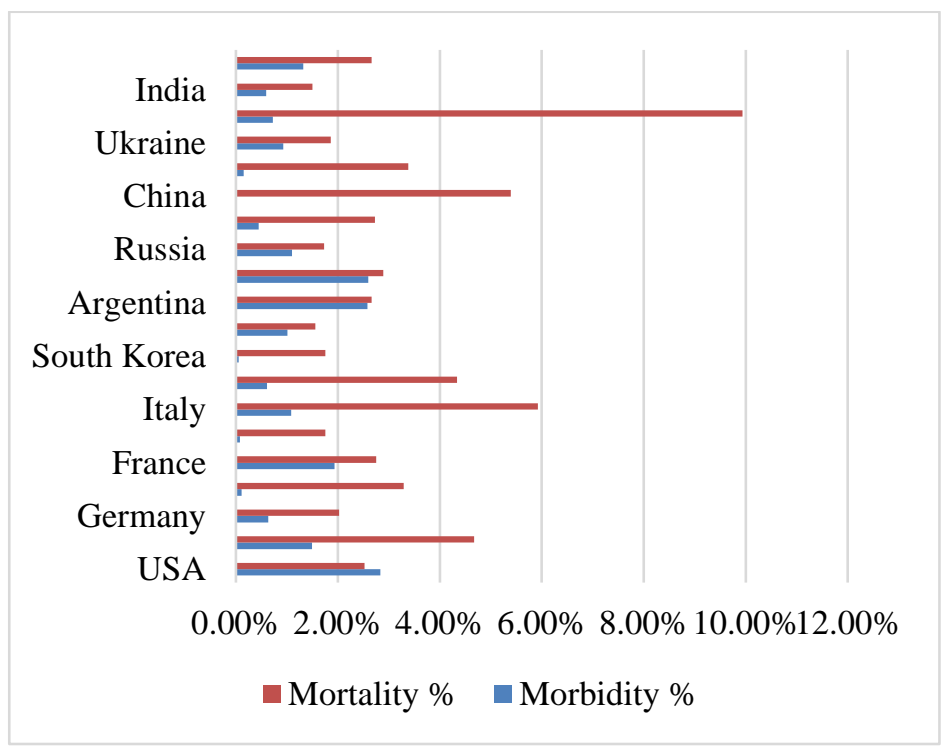

Figure 3. Budget funds spent (in US dollars) per capita.

Data provided by the Ministry of Finance (2020)

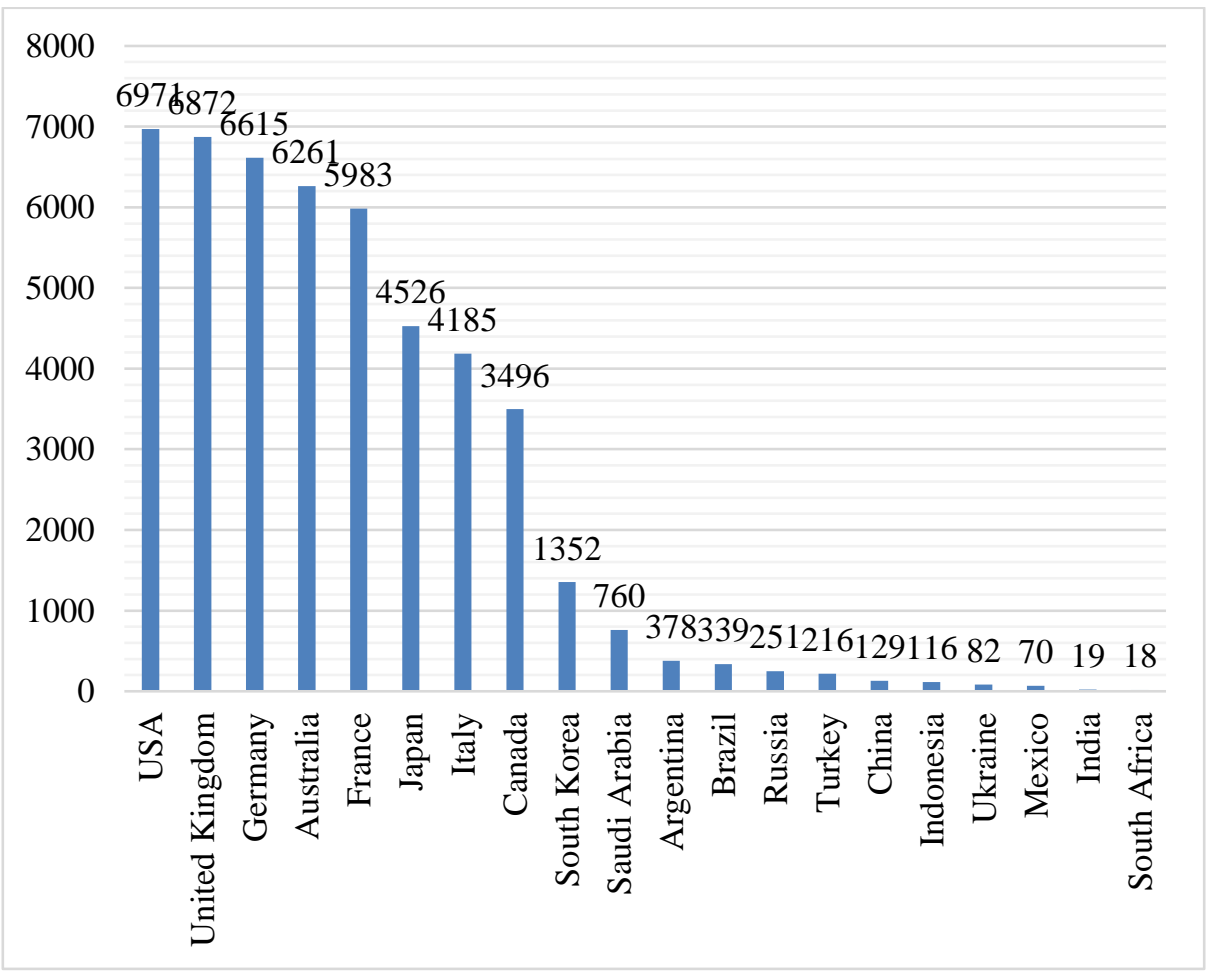


Analyzing current data on indicators such as morbidity, mortality (figure 2) and government spending per capita (figure 3) (Ministry of Finance, 2020) we can see an interesting picture. Even if we take into account that not all countries keep high-quality and honest statistics, there are significant differences even among democratic and transparent systems. It is so obvious that European countries and the United States are seriously inferior in efficiency to Japan and South Korea. The number of cases and deaths in the latter is much lower, but the cost per capita is several times lower. Apparently, the quick reaction of the government and the discipline of the population of the "Asian tigers" made it possible to significantly reduce the number of victims and the consequences for the economy.

Ukraine looks rather mediocre on the mortality and morbidity chart and badly in terms of spending. There is an open deficit of budget funds and spending is planned only for the most necessary - equipment upgrades, the purchase of medicines, the re-equipment of hospitals, additional payments to medical workers.

There is also an additional burden for national economy. To fight the coronavirus, our state resorted to borrowing new credit funds from the European Union, the European Bank for Reconstruction and Development, and the International Monetary Fund. That is, we are also talking about increasing the debt obligations of our state, which ultimately will fall on the shoulders of the real sector of the economy.

However, in addition to the lack of funds, there is also the question of the effectiveness of spending what we have. It is no secret that, for example, in the United States, the public is very closely watching what programs taxpayers' funds go to. In contrast, it seems that the citizens of Ukraine are not particularly worried about the difference whether their funds will be spent on building roads or countering the coronavirus, or, perhaps, additional funding for law enforcement agencies. The corresponding scandals of misuse of the fund against the epidemic have already flared up at the end of the summer (Pershiy, 2020).

Thus, an extremely deplorable picture is emerging, when funds for health care are not enough, the country borrows funds from international lenders, and then they are spent not for their intended purpose. Given the erosion of the existing state regulatory bodies, perhaps the only way out is to ask the United Nations for a special mission to control the targeted use of funds, based on the experience of Japan and South Korea. 


\section{III.3. Exercise of the Right of Derogation}

In its Resolution 74/270 of March 2, 2020, the United Nations General Assembly declared the Covid-19 pandemic a global challenge that requires strong solidarity on the part of the international community in respecting human rights and eliminating all forms of discrimination, racism and xenophobia.

The European Union constantly emphasizes the inadmissibility of violating freedom of expression, freedom of the press, even in a state of emergency. (N1 Belgrado, 2020; Arakelyan, 2020).

It is also known that in March and April 2020, in the context of the Covid-19 pandemic, Latvia, Romania, Armenia, the Republic of Moldova, Estonia, Georgia, Albania, and Northern Macedonia notified the SecretaryGeneral of the Council of Europe of their decision to use Article 15 of the Convention. According to the European Court of Human Rights, at the beginning of April 2020, eight other member states of the European Convention on Human Rights ${ }^{1}$ relied on their right to derogate from the Convention (European Court of Human Rights, 2020).

We are talking about the partial or complete refusal to comply with the European Convention on Human Rights in "emergency situations" such as pandemic.

In the light of the case-law of the European Court of Human Rights on the violation of such rights in the context of Article 15 of the Convention, whenever an applicant complains that his rights under the Convention have been violated during the derogation period, the Court first examines whether the measures taken can be justified under the main articles of the Convention; and only if they cannot be justified in this way does the Court proceed to determine whether the waiver was lawful (for example, Lawless v. Ireland) (Kovalenko, 2020; Kravets, 2020; Kryvorot \& Martynenko, 2020).

Clause 2.1 of the Recommendation to the Member States of the Council of Europe "Respect for Democracy, the Rule of Law and Human Rights in the Crisis Caused by Covid-19" states that even in an emergency, the rule of law should prevail. Many constitutions provide for a special legal regime that increases the powers of the executive in the event of war or a major natural disaster or another calamity. The legislature may also enact emergency laws specifically designed to address crises that go beyond existing legal norms. Any such new legislation must comply with the constitution and international standards and, where applicable, be subject to review by the Constitutional Court (Senyuta, 2020b).

\footnotetext{
${ }^{1}$ Albania, Armenia, France, Georgia, Greece, Ireland, Turkey, and the United Kingdom.
} 
However, the governments of many countries decided to play it safe anyway and, in addition to tightening domestic legislation, de facto have already begun to withdraw their international obligations, which is very alarming for the institution of human rights and freedoms and international cooperation in general. It also carries a risk for the internal political situation in the country, when the role of the Constitutional Court and international law falls, and the executive branch grows. Most likely this was one of the reasons for the unfolding constitutional crisis in Ukraine (Liga.News, 2020).

\section{III.4. The Problem of Legislation in a Pandemic}

One of the main tools for the implementation of the quarantine policy was the tightening of administrative and criminal liability and changes in procedural orders. As already mentioned, the situation with the Art. 325 of the Criminal Code of Ukraine, which was changed, then the changes were rolled back (which leveled all the work on it negatively) affects the basis of legal relations in the country - legal consciousness and legal nihilism.

Changes to the Criminal Procedure Code of Ukraine (2012) have also been criticized by the legal community. In particular, part 2 of Article 27 (publicity and openness of court proceedings) is supplemented by a provision according to which the investigating judge, the court may decide to restrict access of persons who are not participants in the trial to the court hearing during quarantine, if will endanger the life or health of a person. Doubts among lawyers are raised by the expansion of the discretionary powers of the investigating judge, the court in the simultaneous absence of the grounds specified in the law, and clearly defined for such restrictions on the publicity of court hearings (Judicial power of Ukraine, 2020; Tikhomirov, 1995).

No less criticism from human rights defenders was voiced against the Law of Ukraine $n^{\circ}$ 555-IX of March 13, 2020, allowed the processing of personal data for the implementation of anti-epidemic measures without the consent of the person during the quarantine, after which such data are subject to depersonalization or destruction. Such modifications were criticized from the point of view of correctness of placement of norms on the restriction of the constitutional and conventional right to protection of personal information not in the profile law, and item 1 h. 2 of the section "Final and transitional provisions" of the Law $\mathrm{n}^{\circ} 555-\mathrm{IX}$, and also legality restriction of this right in the conditions of introduction of an emergency. This criticism is also confirmed by the fact that the mentioned norm does not clearly establish the circle of persons, and the process of processing such information, which is a literal interpretation, may indicate a violation of the 
principle of legal certainty. The range of subjects in this case can be determined only by referring to the relevant legislation on infectious diseases. The purpose of the introduction of such norm also as following item 6 of h. 2 Art. 7 of the Law of Ukraine "On Personal Data Protection" (2010), consent to the processing of personal data is not required if it is necessary for health purposes, medical diagnosis, etc. (Syrovatskyi, 2019).

Of course, all these errors have an explanation: they wanted to act quickly and did not have time to work out enough, the Verkhovna Rada was often in quarantine and the time for work was limited. However, the very fact that the legislator, with the easy filing of the government, so quickly implements ill-considered decisions in life is already worrisome. We believe that the existing procedures for public discussion at the stages of draft laws should be preserved and even better if their results are more often listened to.

\section{III.5. Threats to Intellectual Property in Healthcare}

According to the report of the World Trade Organization dated March 23,2020 , a ban or restriction on certain groups of goods was imposed by 80 countries. According to the same institution, the groups of goods covered by these restrictions primarily include medical devices, disinfectants, medicines, and tests for the detection of viruses, which does not contradict the general rules of the World Trade Organization, which are mentioned in Art. 11 of the General Agreement on Tariffs and Trade, as otherwise, it would pose a risk of a critical shortage of essential health goods (Shvets, 2019).

In pursuit of reducing access to medicines, treatments, and diagnosing particularly dangerous diseases, countries such as Brazil, Spain, Israel, Germany, and Canada have enacted laws that will allow them to respond quickly to global threats such as Covid-19 in the future. For example, Canada has passed an act that will allow the issuance of compulsory licenses instantly, with a warning from the manufacturer of the drug (Silverman, 2020).

Article 27.2 of the Agreement TRIPS authorizes World Trade Organization members not to allow the patenting of inventions whose commercial use is detrimental to public order or public morals, including the life and health of the population, provided that such prohibition is not limited to restrictions which contained in national law, and paragraph "a" of Art. 27.3 of the Agreement TRIPS provides an opportunity for signatory countries to prohibit the patenting of diagnostic, therapeutic, and surgical treatments for humans or animals. Similar principles are contained in Art. 53 of the European Patent Convention (Shvets, 2019).

It is worth immediately mentioning the work of Fedorov, Kravchenko, Reznichenko, Opara and Tsybokhin (2020), which discusses in detail the 
mechanisms to legally circumvent the restrictions on patents for medicines under the TRIPS agreement. The authors recommend that attention be drawn to India's approach to dealing with patents, taking advantage of the "efficiency gains" gap to enable local manufacturers to manufacture generic drugs without the usual buying or licensing process. However, we consider this approach to be too unfair for the companies of copyright holders and therefore are considering options for other ways.

There are also other mechanisms in international law that will balance intellectual property rights and the public interest. One such tool is the compulsory licensing of inventions which are the subject of a medicinal product, for the purpose of protecting the health of the population (Article 31 of the TRIPS Agreement, in World Trade Organization member countries compulsory licensing rules must comply with this article; $c f$. Shvets, 2019).

It should be noted that before the pandemic, the issuance of compulsory licenses was criticized by both drug owners and the global pharmaceutical business community, but for some reason, we can predict that governments, parliaments, and courts of some countries will conduct a serious revision of their patent policy. However, after mass vaccination (if the vaccine proves effective, which, of course, we all hope now), the giants of the pharmaceutical industry are likely to regain the status quo.

Next, we would like to focus on the institution of compulsory licensing. In Ukraine, the issue of compulsory licensing is regulated by the Law "On protection of industrial design rights" (1994) (Article 30), the Resolution of the Cabinet of Ministers "On approval of the Procedure for granting permission by the Cabinet of Ministers of Ukraine to use a patented invention (utility model)" (2004). In Part 3 of Art. 30 of the Law of Ukraine "On protection of rights to inventions and utility models" (1993) states that to ensure public health, state defense, environmental safety, and other public interests, the Cabinet of Ministers of Ukraine may allow the use of patented inventions (utility models) the owner of the patent in case of his unreasonable refusal to issue a license to use the invention (utility model). The right holder does not lose the right to use the patent independently, in particular, to issue permits for its use to others. Also, the patent owner is paid adequate compensation per the economic value of the invention (utility model; $c f$. Mazurenko, 2020). As we can see, there are mechanisms to reach a consensus between the private and public interests in a pandemic, but we believe that more attention should be paid to ensuring the rights of patent owners and try to find a compromise with them, such as simplified taxation after the pandemic.

One of the few positive aspects of health legislation is the Law "On Amendments to Certain Laws of Ukraine Concerning the Treatment of 
Coronavirus Disease (Covid-19)" amended the Fundamentals of the Legislation of Ukraine on Health Care (1993) and the Draft-Law of Ukraine "On Medicinal Products" (2013). It established that in the interests of treatment of a person with Covid-19, under the procedure approved by this Law and the protocol of the Ministry of Health, may be registered drugs used outside the instructions (off-label), as well as unregistered drugs in Ukraine, recommended by the official body of the United States, the European Union, the United Kingdom, Australia, Canada and the People's Republic of China (Buletsa, 2020).

Such temporary measures can really help the health care system in the state of unfinished reform and there is no point in testing and licensing drugs when there are more pressing problems.

\section{CONCLUSIONS}

1. The search for a balance between public and private interests is largely about human rights and is reflected in aspects such as freedom of movement, freedom of speech and expression, freedom of conscience, religion and belief, access to treatment, access to justice, access to public information, protecting personal data, the rights of the individual to the secrecy of correspondence and to family and private life. These powers are enshrined in major international treaties and national regulations with reservations about their possible limitation under exceptional circumstances. However, the preventive violation of rights and freedoms with the belated lifting of restrictions and disproportionate punishments is an example of a violation of the balance of private interests for the sake of the public interests, but without due effect.

2. There are also many problems with financing the program to combat the pandemic and its consequences. There are not enough funds for health care, the country borrows funds from international lenders, and then they are spent for other purposes. All this harms the interests of every citizen and is an example of ineffective public administration. Considering the above, the only way out we see is a request to the UN for a special mission to control the targeted use of funds, with a focus on the experience of Japan and South Korea.

3. The international trend on the use of the right of derogation is also alarming. The governments of many countries decided to play it safe anyway and, in addition to tightening domestic legislation, de facto have already begun to withdraw their international obligations, which is very alarming for 
the institution of human rights and freedoms and international cooperation in general.

4. Several hasty laws from changing criminal liability and the procedure for handling personal data were more harmful than useful. Hopefully the existing bills, that correct this, will be adopted as soon as possible.

5. The current contradiction between public and private interests in health care is an area where serious mistakes can still be avoided. Having weighed all the risks, it is possible to use either a rather tough "Indian scenario" or to compromise with pharmaceutical companies and work through a compulsory licensing mechanism subject to future benefits for participants.

Taking into account all of the above, it can be concluded that the pandemic has seriously hit the balance between private and public interests. As a result, the latter have become a priority for governments, but in many cases, the benefits from infringement of private interests are disproportionate, since, unfortunately, the government in many situations has acted either not fast enough or simply not efficiently. 


\section{REFERENCES}

Arakelyan, M. R. (2020). Human rights activities in a pandemic. Odessa: Helvetica Publishing House.

Barnes, J. (2018). An Expanding Frontier of Administrative Law: The Public Life of Private Actors. European Public Law, 24(3), 595-612. In https://kluwerlawonline.com/journalarticle/European+Public+Law/24.3/EURO 2018033.

Buletsa, S. B. (April 23, 2020). Features of the contract of controlled access in the conditions of Covid-19. All-Ukrainian scientific and practical online conference. Odesa: Phoenix. In http://dspace.onua.edu.ua/handle/11300/12616.

Chepis, O. I. (April 23, 2020). Ensuring the balance of interests of right holders and society in the application of compulsory licensing in the conditions of Covid-19. All-Ukrainian scientific and practical online conference. Odesa: Phoenix. In http://dspace.onua.edu.ua/handle/11300/12616.

Chervonenko, V. (May 6, 2020). Quarantine in Ukraine: do the new prohibitions contradict the Constitution? BBC Ukraine. In https://www.bbc.com/ukrainian/features52186556?fbclid=IwAR2j13JoswoV4BgILi6cHwwckdEBA3wWcWEAs3j0mZQhohLqwpT7aW6IJw.

Comparato, G. (2017). Public Policy through Private Law: Introduction to a debate on European Regulatory Private Law. European Public Law, 22(5), 621-626. DOI 10.1111/eulj.12199.

Council of Europe. (1963). Protocol $\mathrm{n}^{\circ} 4$ to the Convention for the Protection of Human Rights and Fundamental Freedoms. In https://rm.coe.int/168006b65c.

Dworkin, R. (1978). Taking Rights Seriously. London: Duckworth.

European Court of Human Rights. (2020). Derogation in time of emergency. In https://www.echr.coe.int/Documents/FS_Derogation_ENG.pdf.

Fedorov, V., Kravchenko, S., Reznichenko, H., Opara, N. \& Tsybokhin, O. (2020). Theoretical Problems of Legal Regulation of Innovations in the Medical Field: Experience in Counteracting Covid-19. Ius Humani. Law Journal, 9(2), 251289. DOI 10.31207/ih.v9i2.254

Ferrario, A. \& Kanavos, P. (2013). Managed entry agreements for pharmaceuticals: the European experience. Brussels: EMiNet. 2013. In http://eprints.lse.ac.uk/50513/.

Finnis, J. (2011). Natural Law and Natural Rights. New York: Oxford University Press.

Gabardo, E. (2017). The principle of supremacy of the public interest over private interest as the foundation of Social Administrative Law. Revista de Investigacoes Constitucionais - Journal of Constitutional Research, 4(2), 95-130. In https://doi.org/10.5380/rinc.v4i2.53437. 


\section{Y. Lazur, T. Karabin, O. Martyniuk, O. Bukhanevych \& O. Kanienberh-Sandul}

Galunko, V.V. (2020). Public interest in administrative law. Law Forum, 4, 181-186. In http://www.irbis-nbuv.gov.ua/cgibin/irbis_nbuv/cgiirbis_64.exe?I21DBN=LINK\&P21DBN=UJRN\&Z21ID=\&S $21 \mathrm{REF}=10 \& \mathrm{~S} 21 \mathrm{CNR}=20 \& \mathrm{~S} 21 \mathrm{STN}=1 \& \mathrm{~S} 21 \mathrm{FMT}=\mathrm{ASP} \_$meta $\& \mathrm{C} 21 \mathrm{COM}=\mathrm{S} \& 2$ _S21P03=FILA=\&2_S21STR=FP_index.htm_2010_4_29.

Golosnichenko, D.I. (2020). Social security of citizens in the conditions of coronavirus. Legal Life of Modern Ukraine, 2, 162-165.In http://dspace.onua.edu.ua/bitstream/handle/11300/12624/\%D0\%9F\%D1\%80\% D0\%B0\%D0\%B2\%D0\%BE\%D0\%B2\%D0\%B5\%20\%D0\%B6\%D0\%B8\%D1 $\% 82 \% \mathrm{D} 1 \% 82 \% \mathrm{D} 1 \% 8 \mathrm{~F} \% 20 \% \mathrm{D} 1 \% 81 \% \mathrm{D} 1 \% 83 \% \mathrm{D} 1 \% 87 \% \mathrm{D} 0 \% \mathrm{~B} 0 \% \mathrm{D} 1 \% 81 \%$ D0\%BD\%D0\%BE\%D1\%97\%20\%D0\%A3\%D0\%BA\%D1\%80\%D0\%B0\%D1 $\% 97 \%$ D0\%BD\%D0\%B8\%2C\%202020\%20\%D1\%80.\%2C\%20\%D0\%A2\%D0 $\% \mathrm{BE} \% \mathrm{D} 0 \% \mathrm{BC} \% 202$. pdf?sequence $=1 \&$ isAllowed=y.

Ivashchenko, M.M. \& Nazarets, D.B. (April 23, 2020). Current changes in civil relations in accordance with the resolution of the Cabinet of Ministers of Ukraine "On prevention of the spread of acute respiratory disease Covid-19 in Ukraine, caused by the coronavirus SARSCoV-2”. All-Ukrainian scientific and practical online conference. Odessa: Phoenix. In http://dspace.onua.edu.ua/handle/11300/12616.

Kashintseva, O. Y. \& Trofimenko, M. M. (2020). Use of off-label drugs and unregistered drugs through the prism of intellectual property rights. In https://medcom.unba.org.ua/publications/5427-zastosuvannya-likiv-off-labelta-nezareestrovanih-likars-kih-zasobiv-kriz-prizmu-prava-intelektualnoivlasnosti.html.

Kharytonova, O. I. (April 23, 2020). On the use of off-label drugs (out of instructions) and compassionate use (for reasons of humanity), COVID-19, and new opportunities and challenges in the context of intellectual property protection. All-Ukrainian scientific and practical online conference. Odesa: Phoenix. In http://dspace.onua.edu.ua/handle/11300/12616.

Kolomiets, T. O. (2004). Administrative coercion in the public law of Ukraine: theory, experience and practice of implementation. Zaporozhye: Polygraph.

Konfudorova, L. V. (2020). The concept of "private interest" and its relationship with related legal categories. Law and society, 1(2), 26-32. DOI 10.32842/2078$3736 / 2020.1-2.5$.

Koval, L. V. (2000). State coercion is a method of guaranteeing public safety. Legal sciences, 18, 3-7. In http://ekmair.ukma.edu.ua/handle/123456789/9983?show=full.

Kovalenko, S. (April, 9 2020). Quarantine: the limits of what is allowed. Pravo. In https://pravo.ua/karantin-mezhi-dozvolenogo/.

Kravets, R.Yu. (2020). Human rights interference during a pandemic. In https://protocol.ua/ua/vtruchannya_v_prava_lyudini_pid_chas_pandemii/.

Kryvorot, V. \& Martynenko, A. (2020). Interference in human rights during a pandemic. In https://yur-gazeta.com/publications/practice/inshe/vtruchannya-v-pravalyudini-pid-chas-pandemiyi.html. 
Legal Newspaper Online. (April 7, 2020). Legality of quarantine measures: conclusion of the Kharkiv Human Rights Group. In https://yur-gazeta.com/golovna/zakonnistzaprovadzhennya-karantinnih-zahodiv-visnovok-harkivskoyi-pravozahisnoyigrupi.html.

Liga.News. (November 3, 2020). Constitutional crisis in Ukraine. In https://uanews.liga.net/politics/video/konstitutsiyna-kriza-rada-provodit-zasidannyatranslyatsiya.

Maidanyk, R.A. (2015). Reasonable proportionality and stability in determining the balance of private and public interests is the key to fair expropriation. The Supreme Court of Ukraine. In http://www.viaduk.net/clients/vsu/vsu.nsf/(print)/929B2CC50EAE6EF1C2257 EE7003191E8.

Mazurenko, S. V. (2020). Intellectual property in the field of medicines in the context of the Agreement on Trade-Related Aspects of Intellectual Property Rights (TRIPS). Problems of legal regulation of civil relations in terms of Covid-19, 1, 50-58. In http://dspace.onua.edu.ua/handle/11300/12616.

McBride, J. (2020). An Analysis of Covid-19 Responses and ECHR Requirements. ECHR Blog. In http://echrblog.blogspot.com/2020/03/an-analysis-of-covid-19responses-and.html.

N1 Belgrade (April 24, 2020). EU spokeswoman: Emergency measures must be limited. In http://rs.n1info.com/English/NEWS/a591148/EU-spokeswoman-Emergencymeasures-must-be-limited.html.

Pershiy. (September 8, 2020). In Ukraine, a new anti-record was recorded in the number of deaths due to COVID-19 per day. Five Channel. In https://www.5.ua/ru/polytyka/vlast-dyletantov-poteriala-kontrol-nad-covid-19es-trebuet-rassledovat-netselevoe-yspolzovanye-hossredstv-223522.html.

Safarov, A. (March 23, 2020). Special conditions in the country are not grounds for secrecy of socially important information. Institute of Mass Media. In https://imi.org.ua/monitorings/osoblyvi-umovy-v-krayini-ne-ye-pidstavoyudlya-utayemnychennya-suspilno-vazhlyvoyi-informatsiyi-i32295.

Savchenko, S. V. (2013). The ratio of private and public interests: the experience of Ukraine. Comparative and analytical law, 3(2), 53-57. In http://www.irbisnbuv.gov.ua/cgi-

bin/irbis_nbuv/cgiirbis_64.exe?I21DBN=LINK\&P21DBN=UJRN\&Z21ID=\&S $21 \mathrm{REF}=10 \& \mathrm{~S} 21 \mathrm{CNR}=20 \& \mathrm{~S} 21 \mathrm{STN}=1 \& \mathrm{~S} 21 \mathrm{FMT}=\mathrm{ASP} \_$meta\&C21COM=S\&2 _S21P03=FILA=\&2_S21STR=FP_index.htm_2013_3_87.

Savchuk, V. (June 9, 2020). Boom of labor law. VK. In http://vkp.ua/publication/bum-natrudove-pravo.

Schukin, O. S. (2020). Some aspects of the regulation of labor relations during the quarantine period. Legal life of modern Ukraine, 2, 173-177. In http://dspace.onua.edu.ua/handle/11300/12769.

Senyuta, I. (March 3, 2020a). Is there a legal restriction on quarantine under the conditions of coronavirus. Legal Newspaper Online. In https://yur- 


\section{Y. Lazur, T. Karabin, O. Martyniuk, O. Bukhanevych \& O. Kanienberh-Sandul}

gazeta.com/dumka-eksperta/chi-zakonne-obmezhennya-na-karantin-za-umovkoronavirusa-2019.html.

Senyuta, I. Ya. (2020b). Processing of personal data under the new rules: protection or violation of human rights. Higher School of Advocacy. In https://www.hsa.org.ua/blog/obrobka-personalnyh-danyh-v-umovah-covid-19zahyst-chy-porushennya-prav-lyudyny/.

Shvets, Yu. Yu. (2019). Realization of a person's constitutional right to health care: a comparative legal study. Uzhhorod: Uzhhorod National University. In https://www.uzhnu.edu.ua/uk/infocentre/get/19675.

Silverman, Ed. (March 25, 2020). A Canadian bill would make it easier to issue compulsory licenses for Covid-19 products. Stat. In https://www.statnews.com/pharmalot/2020/03/25/canada-compulsory-licensecoronavirus-covid19/.

Slusar, A. \& Novikova, M. (May 9, 2020). Criminal Justice in Steampunk format. VK. In https://vkp.ua/ua/publication/kriminalna-yustitsiya-v-formati-steampunk.

Strauss, P. (2016). The troubling conjunction of public and private law. Comparative Law and Regulation: Understanding the Global Regulatory Process, 1, 385-402.

Syrovatskyi, V.I. (2019). Epistemological conditionality of state coercion as a motivation to comply with legal norms. Scientific Bulletin of Public and Private Law, 4(2), 247-252. DOI 10.32844/2618-1258.2019.4-2.46.

Tikhomirov, Yu.A. (1995). Public law. Moscow: BEC. In http://www.kursach.com/biblio/0010028/000.htm.

Ukraine. (1984). Code of Ukraine on Administrative Offenses: Law. In https://zakon.rada.gov.ua/laws/show/80731-10.

Ukraine. (1993). Fundamentals of the Legislation of Ukraine on Health Care. In https://zakon.rada.gov.ua/laws/show/2801-12\#Text.

Ukraine. (1993). On protection of rights to inventions and utility models: Law 3687-XII. In https://zakon.rada.gov.ua/laws/show/3687-12\#Text.

Ukraine. (1994). On protection of industrial design rights: Law. In https://zakon.rada.gov.ua/laws/show/3688-12\#Text.

Ukraine. (2000). On protection of the population against infectious diseases: Law 1645 III. In https://zakon.rada.gov.ua/laws/show/1645-14\#Text.

Ukraine. (2000). On the legal regime of the state of emergency: Law 1550-III. In https://zakon.rada.gov.ua/laws/show/1550-14\#Text.

Ukraine. (2002). Criminal Code of Ukraine. In https://zakon.rada.gov.ua/laws/show/234114/conv\#n19.

Ukraine. (2004). Civil Procedure Code of Ukraine: Law 1618-IV. In https://zakon.rada.gov.ua/laws/show/1618-15.

Ukraine. (2004). On Freedom of Movement and Free Choice of Residence in Ukraine: Law. In https://zakon.rada.gov.ua/laws/show/1382-15\#Text. 
Ukraine. (2010). On Personal Data Protection: Law 2297-VI. In https://zakon.rada.gov.ua/laws/show/2297-17\#Text.

Ukraine. (2011). On the Cabinet of Ministers of Ukraine: Law. In https://zakon.rada.gov.ua/laws/show/2591-17\#Text.

Ukraine. (2013). On Medicinal Products: Draft-Law. In http://search.ligazakon.ua/1_doc2.nsf/link1/JG21K00A.html.

Ukraine. (2014). On Prevention of Corruption: Law 1700-VII. In https://zakon.rada.gov.ua/laws/show/1700-18\#Text.

Ukraine. (2014). On the Cabinet of Ministers of Ukraine: Law 794-VII. In https://zakon.rada.gov.ua/laws/show/794-18\#Text.

Ukraine. (2020). On Amendments to Certain Legislative Acts of Ukraine Aimed at Providing Additional Social and Economic Guarantees in Connection with the Spread of Coronavirus Disease (Covid-19): Law 540-IX. In https://zakon.rada.gov.ua/laws/show/540-20.

Ukraine. (2020). On Amendments to Certain Legislative Acts of Ukraine Aimed at Preventing the Occurrence and Spread of Coronavirus Disease (Covid-19): Law 530-IX. In https://zakon.rada.gov.ua/laws/show/530-20.

Ukraine. (2020). On Amendments to the Law of Ukraine "On Protection of the Population from Infectious Diseases" on Prevention of the Spread of Coronavirus Disease (Covid-19): Law 555-IX. In https://zakon.rada.gov.ua/laws/show/555-20.

Ukraine. Cabinet of Ministers of Ukraine. (2004). On approval of the Procedure for granting permission by the to use a patented invention (utility model): Resolution. In https://zakon.rada.gov.ua/laws/show/8-2004-\%D0\%BF\#Text.

Ukraine. Cabinet of Ministers of Ukraine. (2020). Resolution 392. In https://zakon.rada.gov.ua/laws/show/392-2020-\%D0\%BF\#Text.

Ukraine. Constitutional Court of Ukraine. (2004). Decision 18-rp/2004. In https://zakon.rada.gov.ua/laws/show/v018p710-04\#Text.

Ukraine. Judicial Power. (2020). Procedural codes are supplemented by provisions on the peculiarities of consideration of cases in the context of quarantine measures. In https://court.gov.ua/press/news/920242/.

Ukraine. Ministry of Finance. (2020). Coronavirus: statistics by country. In https://index.minfin.com.ua/reference/coronavirus/geography/.

Ukraine. Ministry of Health. (2020). On approval of the protocol "Provision of medical care for the treatment of coronavirus disease (Covid-19)": Order 762. In https://moz.gov.ua/article/ministry-mandates/nakaz-moz-ukraini-vid-2042020-762-pro-zatverdzhennja-protokolu-nadannja-medichnoi-dopomogi-dljalikuvannja-koronavirusnoi-hvorobi-covid-19.

Ukraine. State Juridical Administration. (2020). Operational information on the consideration of cases under Article 44-3 "Violation of the rules on human quarantine" as of June 30, 2020. In https://dsa.court.gov.ua/dsa/prescentr/general/962387/. 


\section{Y. Lazur, T. Karabin, O. Martyniuk, O. Bukhanevych \& O. Kanienberh-Sandul}

United Nations. (1948). Universal Declaration of Human Rights. In https://www.un.org/en/universal-declaration-human-rights/.

United Nations. (1950). Convention for the Protection of Human Rights and Fundamental Freedoms. In https://www.echr.coe.int/documents/convention_eng.pdf

United Nations. (2020). Global solidarity to fight the coronavirus disease 2019 Covid-19: Resolution 74/270. In https://undocs.org/en/A/RES/74/270.

Varuhas, J. N. E. (2016). The Public Law-Private Law Distinction. Damages and Human Rights, 1, 167-225.

Wenzl, M. \& Chapman, S. (2019). Performance-based managed entry agreements for new medicines in OECD countries and EU member states. How they work and possible improvements going forward. Health Working Papers OECD, 115, 45. In https://www.oecd.org/health/health-systems/HWP-115-MEAs.pdf.

World Trade Organization. (1994). Trade-Related Aspects of Intellectual Property Rights. In https://www.wto.org/english/tratop_e/trips_e/trips_e.htm.

Yarovyi, A. (March 24, 2020). Violations of human rights during a pandemic: where is the limit? In

https://lb.ua/blog/anatolii_yarovyi/453463_porushennya_prav_lyudini_pid_cha s.html.

Zaliska, O. M. \& Stasiv, H.-O. I. (2019). "Managed access agreements” for innovative medicines to ensure the availability of drugs in European countries. Apteka. In https://www.apteka.ua/article/500494.

Zharovska, I.M. (2010). Public and private interests in the mechanism of modern state power. Scientific Bulletin of Chernivtsi University, 525, 33-37. 